University of Nebraska - Lincoln

DigitalCommons@University of Nebraska - Lincoln

Faculty Publications, Department of Psychology

Psychology, Department of

2009

\title{
Immune Responses to Methamphetamine by Active Immunization with Peptide-Based, Molecular Adjuvant-Containing Vaccines
}

\author{
Michael J. Duryee \\ Omaha Veterans Administration Medical Center \\ Rick A. Bevins \\ University of Nebraska-Lincoln, rbevins1@unl.edu \\ Carmela M. Reichel \\ University of Nebraska-Lincoln \\ Jennifer E. Murray \\ University of Nebraska-Lincoln, jem98@cam.ac.uk \\ Yuxiang Dong \\ University of Nebraska Medical Center, 986025 Nebraska Medical Center, Omaha, NE \\ See next page for additional authors
}

Follow this and additional works at: https://digitalcommons.unl.edu/psychfacpub

Part of the Psychiatry and Psychology Commons

Duryee, Michael J.; Bevins, Rick A.; Reichel, Carmela M.; Murray, Jennifer E.; Dong, Yuxiang; Thiele, Geoffrey M.; and Sanderson, Sam D., "Immune Responses to Methamphetamine by Active Immunization with Peptide-Based, Molecular Adjuvant-Containing Vaccines" (2009). Faculty Publications, Department of Psychology. 366.

https://digitalcommons.unl.edu/psychfacpub/366

This Article is brought to you for free and open access by the Psychology, Department of at DigitalCommons@University of Nebraska - Lincoln. It has been accepted for inclusion in Faculty Publications, Department of Psychology by an authorized administrator of DigitalCommons@University of Nebraska - Lincoln. 


\section{Authors}

Michael J. Duryee, Rick A. Bevins, Carmela M. Reichel, Jennifer E. Murray, Yuxiang Dong, Geoffrey M. Thiele, and Sam D. Sanderson 


\title{
Immune responses to methamphetamine by active immunization with peptide-based, molecular adjuvant-containing vaccines
}

\author{
Michael J. Duryee ${ }^{\mathrm{a}, \mathrm{b}}$, Rick A. Bevins ${ }^{\mathrm{c}}$, Carmela M. Reichel ${ }^{\mathrm{c}}$, Jennifer E. Murray ${ }^{\mathrm{c}}$, \\ Yuxiang Dong ${ }^{\mathrm{d}}$, Geoffrey M. Thiele ${ }^{\mathrm{a}, \mathrm{b}, \mathrm{e}}$, Sam D. Sanderson ${ }^{\mathrm{f}, *}$ \\ a Experimental Immunology Laboratory, Omaha Veterans Administration Medical Center, Research Services 151, 4101 Woolworth Avenue, Omaha, NE 68105, United States \\ ${ }^{\mathrm{b}}$ Department of Pathology and Microbiology, University of Nebraska Medical Center, 986495 Nebraska Medical Center, Omaha, NE 68198-6495, United States \\ c Department of Psychology, University of Nebraska - Lincoln, 238 Burnett Hall, Lincoln, NE 68588-0308, United States \\ d Department of Pharmaceutical Sciences, University of Nebraska Medical Center, 986025 Nebraska Medical Center, Omaha, NE 68198-6025, United States \\ e Experimental Immunology Laboratory, Department of Internal Medicine, Section of Rheumatology, University of Nebraska Medical Center, 983025 Nebraska Medical Center, \\ Omaha, NE 68198-3025, United States \\ f School of Allied Health Professions, University of Nebraska Medical Center, 984000 Nebraska Medical Center, Omaha, NE 68198-4000, United States
}

\section{A R T I C L E I N F O}

\section{Article history:}

Received 4 December 2008

Received in revised form 11 February 2009

Accepted 24 February 2009

Available online 10 March 2009

\section{Keywords:}

Conformationally biased

Response-selective C5a agonists

Molecular adjuvant

Methamphetamine vaccine

Anti-methamphetamine antibodies

Self-administration

\begin{abstract}
A B S T R A C T
Vaccines to methamphetamine (meth) were designed by covalently attaching a meth hapten (METH) to peptide constructs that contained a conformationally biased, response-selective molecular adjuvant, YSFKPMPLaR (EP54). Rats immunized with EP54-containing meth vaccines generated serum antibody titers to authentic meth, an immune outcome that altered meth self-administration. Immunization increased meth self-administration suggesting pharmacokinetic antagonism. The ability of immune sera to bind a METH-modified target protein dramatically decreased during and shortly after the meth selfadministration assay, suggesting effective sequestration of free meth. However, the binding ability of immune sera to the METH-modified target protein was recovered 34 days after meth-free clearance time.
\end{abstract}

\section{Introduction}

The illicit manufacture, distribution, and abuse of methamphetamine (meth) have risen dramatically in the past decade imposing enormous public health, welfare, and law enforcement burdens worldwide. Meth represents the fastest growing drug threat in the United States [1] and is a major problem in the American Midwest [1-3], a rural region that provides access to agricultural ammonia, a key ingredient in its illicit synthesis, and a remote setting that enables makeshift laboratories to operate in a more clandestine manner. Of particular concern is the strong association between this increase in meth abuse and the transmission of communicable diseases such as hepatitis A [4].

The scourge of meth abuse and its devastating effects on society and family life underscore the need for an effective method of inhibiting its addictive, pharmacologic effects. Presently, no direct intervention method exists, the mainstay of therapy being behavior modification and treatment with antidepressants to help a patient

\footnotetext{
* Corresponding author. Tel.: +1 4025595353.

E-mail address: sdsander@unmc.edu (S.D. Sanderson).
}

through withdrawal. A bothersome issue with a highly addictive drug like meth, however, is the high rate of relapse [5-8]. Thus, a therapy is urgently needed that is capable of (1) effectively antagonizing the drug in circulation prior to its distribution to the brain and (2) sustaining this antagonizing effect long enough to minimize relapse. Such a therapy, when used as a complement to standard treatments, would provide a powerful combination approach for treating meth addiction.

An innovative therapeutic approach capable of providing these latter two attributes is immunization with an appropriately designed meth vaccine. Vaccination will induce the immune system to generate meth-specific antibodies (Ab), which will bind free meth in circulation with high affinity, thus decreasing/altering meth distribution to the brain. Also, vaccination has the potential of sustaining this anti-meth immune response in the face of repeated ingestions of meth and for a period of time beyond the initial cessation of meth use, thus providing protection during that crucial time frame when the patient is highly susceptible to relapse. Also, the antagonizing effects of such an immunologic approach would occur outside the central nervous system (CNS) and would not interfere with behavior modification or CNS-acting medications. 
Vaccines to cocaine [9,10], heroin [11], and nicotine [12-15] have been used in the active immunization of rats and shown capable of producing high sera titers of drug-specific Abs, which attenuated the psychoactive and locomotor effects of subsequent drug challenges. These vaccines were generated via conventional designs wherein multiple drug haptens were covalently conjugated to a carrier protein, which was then admixed with an adjuvant for the deliverable drug vaccine.

Byrnes-Blake et al. [16] showed appreciable serum titers of anti-meth Abs in rats immunized with a similarly designed meth vaccine. Importantly, they showed that neither $A b$ titer nor $A b$ affinity were affected by the concomitant administration of meth during the course of immunization, suggesting that meth use during a patient's immunization schedule (a likely scenario) will not adversely affect the production of anti-meth Abs. Unfortunately, this anti-meth $\mathrm{Ab}$ response was ineffective in attenuating locomotor activities in rats challenged with meth, suggesting that the vaccine design and/or its administration schedule were not optimized.

In this paper we describe the design of novel, peptide-based, molecular adjuvant-containing vaccines to meth and their use in producing short-term and long-term anti-meth outcomes in rats. The vaccines used in this study were composed of three basic components, the first being the molecular adjuvant, YSFKPMPLaR (EP54), which is a conformationally biased, response-selective agonist of complement component $\mathrm{C}_{5} \mathrm{a}_{65-74}$. EP54 retains C5a-like immune stimulatory properties, but with significantly reduced C5a-like inflammatory properties [17-20]. The role of the molecular adjuvant EP54 in these vaccines is to target covalently attached Ags to and activate the $\mathrm{Ag}$ processing and presentation capacity of C5a receptor-bearing antigen presenting cells [21-23], particularly dendritic cells (DCs) [24].

The second vaccine component is a T-cell epitope from tetanus toxin $\mathrm{TT}_{593-599}$ (YSYFPSV) [25], which was covalently attached to the N-terminus of EP54. This epitope was used to engage CD4 ${ }^{+}$ helper T-cells in order to provide the necessary T-cell help for the Ab-producing B cells during epitope/hapten presentation by DCs activated by EP54. The third component is a meth hapten (METH) synthesized to allow the covalent attachment (via amide bond formation) to either the N-termini of the TT epitope-EP54 peptide or EP54 (monovalent vaccines) or also to the $\varepsilon$-amino group of an extra Lys residue, which was added to the $\mathrm{N}$-terminal end of the TT epitope-EP54 peptide or EP54 (divalent vaccines).

In this paper we present the immunologic outcomes of rats vaccinated with these EP54-containing vaccines in terms of initial and sustained meth-specific serum Ab titers and their ability to attenuate/alter meth self-administration. These results are discussed against the backdrop of such an immunologic approach being used as a routine method of treating meth abuse/addiction.

\section{Materials and methods}

\subsection{Peptide synthesis}

Peptides were synthesized by standard solid phase methods on an Aapptec Apex 396 synthesizer using the Fmoc (9-fluorenylmethoxycarbonyl) method of orthogonal synthesis on a pre-loaded Fmoc-Arg Wang resin. Peptides were purified by preparative and analytical HPLC and characterized by confirmation of molecular mass with MALDI mass spectrometry (see below).

\subsection{Hapten (METH) synthesis (Scheme 1)}

The METH hapten shown in Scheme 1 was synthesized by a modification of the basic scheme described by Byrnes-Blake et al. [16]. Confirmation of the chemical modifications contained in our homologues, as well as synthetic yields, were consistent with those reported for the parent hapten [16].

\subsection{1. (S)-N-methyl-N-(1-methyl-2-phenylethyl)acetamide (2)}

$\mathrm{S}-(+)$ methamphetamine (1) $(2.23 \mathrm{~g}, 14.9 \mathrm{mmol})$ was dissolved in $100 \mathrm{ml}$ dichloromethane $\left(\mathrm{CH}_{2} \mathrm{Cl}_{2}\right)$ containing five equivalents $(10.4 \mathrm{ml}$ ) of triethylamine (TEA). To this stirred solution was added $18 \mathrm{mmol}$ (1.42 g) of acetyl chloride dropwise over $10 \mathrm{~min}$. This solution was stirred overnight at room temperature and the solvent removed in vacuo. The residue was dissolved in $\mathrm{CH}_{2} \mathrm{Cl}_{2}(75 \mathrm{ml})$,

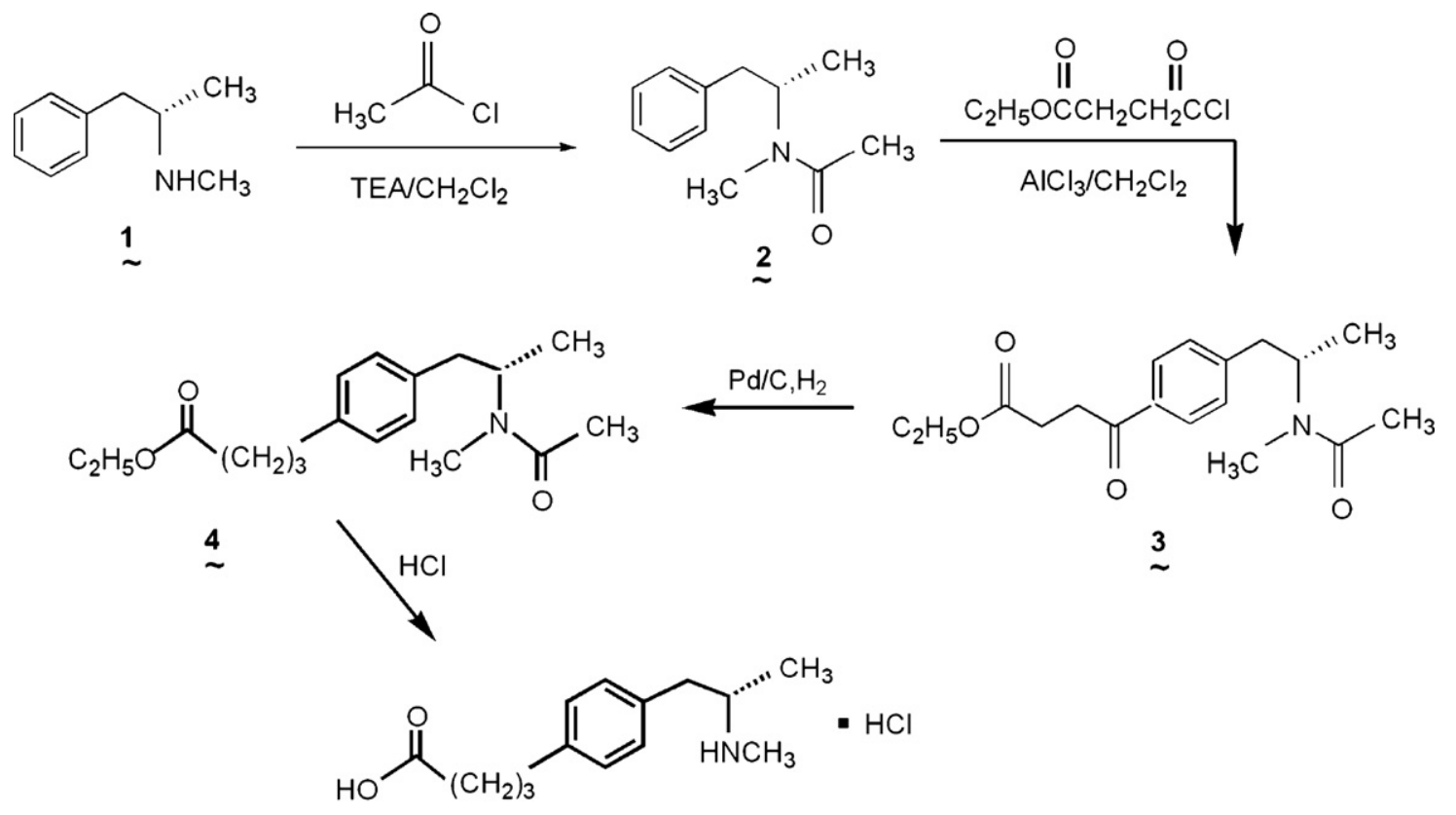

5 METH

Scheme 1. 
washed two times each with $1 \mathrm{~N} \mathrm{HCl}$, saturated brine, water, and dried over $\mathrm{Mg}_{2} \mathrm{SO}_{4}$. The $\mathrm{CH}_{2} \mathrm{Cl}_{2}$ was removed in vacuo to yield S(+)-N-acetylmethamphetamine (2) as a light brown oil. The NMR spectra indicated a 1:1-mixture of rotamers. ${ }^{1} \mathrm{H}$ NMR $(500 \mathrm{MHz}$, $\left.\mathrm{CDCl}_{3}\right) \delta 1.10(\mathrm{~d}, J=6.8 \mathrm{~Hz}, 1.5 \mathrm{H}), 1.26(\mathrm{~d}, J=6.4 \mathrm{~Hz}, 1.5 \mathrm{H}), 1.75(\mathrm{~s}$, $1.5 \mathrm{H}), 1.98(\mathrm{~s}, 1.5 \mathrm{H}), 2.64-2.82(\mathrm{~m}, 2 \mathrm{H}), 2.78(\mathrm{~s}, 1.5 \mathrm{H}), 2.85(\mathrm{~s}, 1.5 \mathrm{H})$, 3.96-4.09 (m, 0.5H), 4.99-5.09 (m, 0.5H), 7.09-7.35 (m, 5H). MF, $\mathrm{C}_{12} \mathrm{H}_{17} \mathrm{NO} ; \mathrm{MH}^{+}=192$.

\subsection{2. (S)-4-[2-(acetylmethylamino)propyl]- $\gamma$-oxobenzenebut-} anoic acid ethyl ester (3)

To a mixture of compound $2(5.38 \mathrm{~g}, 28.13 \mathrm{mmol})$ in $\mathrm{CH}_{2} \mathrm{Cl}_{2}$ $(100 \mathrm{ml})$ at $0{ }^{\circ} \mathrm{C}$ was added ethyl succinyl chloride $(9.26 \mathrm{~g}$, $56.26 \mathrm{mmol})$ followed by $\mathrm{AlCl}_{3}(17.87 \mathrm{~g}, 134 \mathrm{mmol})$ in three portions. The reaction was stirred overnight at room temperature, cooled to $0^{\circ} \mathrm{C}$, and quenched with $3 \mathrm{M}$ aqueous $\mathrm{HCl}(100 \mathrm{ml})$. After the mixture was diluted with $\mathrm{CH}_{2} \mathrm{Cl}_{2}(100 \mathrm{ml})$, the organic layer was separated, washed with $3 \mathrm{M}$ aqueous $\mathrm{HCl}(100 \mathrm{ml})$ and water $(200 \mathrm{ml})$, dried over $\mathrm{MgSO}_{4}$, and concentrated to give a crude product $(14.18 \mathrm{~g})$ that was used in the next step without further purification. The NMR spectra indicated 3:2-mixture of rotamers. ${ }^{1} \mathrm{H} \mathrm{NMR}\left(500 \mathrm{MHz}, \mathrm{CDCl}_{3}\right) \delta 1.14(\mathrm{~d}, J=6.4 \mathrm{~Hz}, 1.8 \mathrm{H}), 1.27(\mathrm{t}, J=6.9 \mathrm{~Hz}$, $3 \mathrm{H}), 1.28(\mathrm{~d}, J=6.4 \mathrm{~Hz}, 1.2 \mathrm{H}), 1.81(\mathrm{~s}, 1.2 \mathrm{H}), 2.02(\mathrm{~s}, 1.8 \mathrm{H}), 2.61-2.92$ $(\mathrm{m}, 4 \mathrm{H}), 2.80(\mathrm{~s}, 1.8 \mathrm{H}), 2.87(\mathrm{~s}, 1.2 \mathrm{H}), 3.29(\mathrm{t}, J=6.6 \mathrm{~Hz}, 2 \mathrm{H}), 4.01-4.11$ $(\mathrm{m}, 0.4 \mathrm{H}), 4.16(\mathrm{q}, J=6.9 \mathrm{~Hz}, 2 \mathrm{H}), 5.01-5.11(\mathrm{~m}, 0.6 \mathrm{H}), 7.19-7.36(\mathrm{~m}$, $2 \mathrm{H}), 7.85-7.98$ (m, 2H).

\subsection{3. (S)-4-[2-(acetylmethylamino)propyl]benzenebutanoic acid ethyl ester (4)}

A mixture of compound 3 ( $14.18 \mathrm{~g}$, crude product from the last step) and $10 \mathrm{wt} \% \mathrm{Pd} / \mathrm{C}(1.40 \mathrm{~g})$ in acetic acid $(50 \mathrm{ml})$ was stirred at room temperature under $\mathrm{H}_{2}$ atmosphere for $48 \mathrm{~h}$. After the mixture was filtered and rinsed with $\mathrm{CH}_{2} \mathrm{Cl}_{2}(200 \mathrm{ml})$, the filtrate was diluted with $\mathrm{CH}_{2} \mathrm{Cl}_{2}(100 \mathrm{ml})$, washed with water $(200 \mathrm{ml})$ and saturated aqueous $\mathrm{NaHCO}_{3}(100 \mathrm{ml})$, dried over $\mathrm{MgSO}_{4}$, and concentrated to give compound 4 as a brown oil $(6.97 \mathrm{~g}, 81 \%$; the combined yield for the last two steps). The NMR spectra indicated 1:1-mixture of rotamers. ${ }^{1} \mathrm{H}$ NMR $\left(500 \mathrm{MHz}, \mathrm{CDCl}_{3}\right) \delta 1.09$ (d, $J=6.8 \mathrm{~Hz}, 1.5 \mathrm{H}), 1.24(\mathrm{~d}, J=6.8 \mathrm{~Hz}, 1.5 \mathrm{H}), 1.25(\mathrm{t}, J=6.8 \mathrm{~Hz}, 3 \mathrm{H})$, $1.75(\mathrm{~s}, 1.5 \mathrm{H}), 1.88-1.96(\mathrm{~m}, 2 \mathrm{H}), 1.99(\mathrm{~s}, 1.5 \mathrm{H}), 2.30(\mathrm{t}, J=7.6 \mathrm{~Hz}, 2 \mathrm{H})$, $2.56-2.81(\mathrm{~m}, 4 \mathrm{H}), 2.78(\mathrm{~s}, 1.5 \mathrm{H}), 2.84(\mathrm{~s}, 1.5 \mathrm{H}), 3.95-4.06(\mathrm{~m}, 0.5 \mathrm{H})$, 4.09-4.19 (m, 2H), 4.95-5.06 (m, 0.5H), 6.98-7.15 (m, 4H).

\subsection{4. (S)-4-[2-(methylamino)propyl]benzenebutanoic acid hydrochloride (5) (METH).}

A mixture of compound $4(6.97 \mathrm{~g}, 22.8 \mathrm{mmol})$ and $6 \mathrm{M}$ aqueous $\mathrm{HCl}(120 \mathrm{ml})$ was refluxed for $72 \mathrm{~h}$. After cooling to room temperature, the mixture was concentrated in vacuo. The residue was purified by crystallization from ether followed by crystallization from acetonitrile to give the desired compound $\mathbf{5}$ as a colorless solid $(2.10 \mathrm{~g}, 34 \%) \mathrm{mp} 130-132{ }^{\circ} \mathrm{C} .{ }^{1} \mathrm{H}$ NMR $(500 \mathrm{MHz}$, DMSO-d 6 ) $\delta 1.08(\mathrm{~d}, J=6.3 \mathrm{~Hz}, 3 \mathrm{H}), 1.71-1.82(\mathrm{~m}, 2 \mathrm{H}), 2.19(\mathrm{t}, J=7.1 \mathrm{~Hz}, 2 \mathrm{H})$, 2.51-2.64 (m, 6H), 3.08-3.18 (m, 1H), 3.25-3.34 (m, 1H), $7.15(\mathrm{~s}$, 4H), 9.04 (brs, 2H), 12.05 (s, 1H); ${ }^{13} \mathrm{C}$ NMR (125.7 MHz, DMSO-d $\left.\mathrm{d}_{6}\right) \delta$ $15.15,26.40,29.71,33.24,34.15,38.05,55.44,128.71,129.40,134.25$, $140.20,174.40$

\subsection{Vaccine synthesis}

Monovalent (METH-YSFKPMPLaR and METH-YSYFPSVYSFKPMPLaR) and divalent (METH-K(METH)YSFKPMPLaR and METHK(METH)YSYFPSVYSFKPMPLaR) vaccines were generated by coupling METH (5) to the $\mathrm{N}$-terminal and $\varepsilon$-amino moieties of these peptides while attached to the solid phase resin [15]. The corresponding free amino groups were generated by selective deprotection of Fmoc groups and amide bond formation with METH was achieved by reaction with the HBTU (2-(1H-benzotriazol-1-yl)1,1,3,3-tetramethyluronium hexafluorophosphate)-activated ester of METH. The course of this coupling reaction was monitored by the loss of the free amine on the peptide with ninhydrin. The peptide-based vaccines were cleaved from the resin and side-chain protecting groups removed by stirring the resin for $1.5 \mathrm{~h}$ at room temperature in a cleavage cocktail made of TFA (92.5\%), water (5\%), and triisopropylsilane (2.5\%). To this solution was added an excess (ca. $100 \mathrm{ml}$ ) of cold ether to precipitate the peptide, which was then collected by centrifugation. Peptides were purified by analytical and preparative reverse-phase HPLC on C18-bonded silica columns with a running buffer of $0.1 \%$ TFA (Solvent $A$ ) and $60 \%$ acetonitrile in $0.1 \%$ TFA (Solvent B) as the eluant. Peptides were characterized by confirmation of molecular mass using MALDI mass spectrometry.

\subsection{Vaccination}

Rats were randomly assigned to either the Vaccine or Control group. The Vaccine group received two injections of $250 \mu \mathrm{g}$ of vaccine dissolved at $1 \mathrm{mg} / \mathrm{ml}$ in sterile water. One injection was subcutaneous (SC) and the other was intraperitoneal (IP). The Control group received the same number and volume of vehicle injections. This vaccination procedure was repeated once every 7 days for 5 weeks and serum was collected at weeks 1,3 , and 6 . The final vaccination occurred on the last day of Preliminary Training (see below).

\subsection{Determination of Abs to methamphetamine}

Prior to immunization of meth administered rats a group was tested to determine vaccine efficacy. Briefly, 4 rats were immunized with vaccine as described above and bled via retro orbital puncture. A direct ELISA was used to determine circulating antibody titers to meth. Serum was diluted 2 -fold and multiple dilutions were averaged to determine concentration from the rat IgG standard curve. Using METH-modified BSA (bovine serum albumin), ELISA plates (Immulon IV, Dynatech, Chantilly, VA) were coated at $2 \mu \mathrm{g} /$ well in the presence of bicarbonate buffer, pH 9.6 and incubated at $37^{\circ}$ overnight. Plates were washed, blocked using $2 \%$ casein for $30 \mathrm{~min}$ and rat serum incubated on the plate for $1 \mathrm{~h}$ at room temperature. The plates were then washed and horse raddish peroxidase (HRP) rabbit anti-rat IgG (H\&L) antibody added (Sigma Chemical, Co., St. Louis, MO), incubated for $30 \mathrm{~min}$, and developed using TMB substrate. Absorbance was detected at $450 \mathrm{~nm}$ using an MRX II Microplate Reader (Dynatech, Chantilly, VA), data analyzed using Revelations Software from Dynatech, and expressed in $\mathrm{ng} / \mathrm{ml}$ using rat IgG as a standard curve.

\subsection{Competitive ELISA}

In order to determine the specificity of the Abs raised against meth, a competitive ELISA was used as previously described [15]. ELISA plates were coated with METH-modified BSA as described above and incubated overnight. In a separate radioimmuno-assay (RIA) plate, the meth inhibitor and serum were diluted for overnight incubation at $4{ }^{\circ} \mathrm{C}$. Meth was diluted 2 -fold down the plate at a starting concentration of $2000 \mathrm{pmol} /$ well. Serum from immunized rats was added to the plate at a concentration that would produce a 1.0 O.D. after $30 \mathrm{~min}$ of incubation. Following an overnight incubation, the plate was washed, blocked in $2 \%$ casein, and the RIA plate contents transferred over. After $1 \mathrm{~h}$ incubation at room temperature, the plate was washed and an HRP rabbit anti-rat IgG (H\&L) (from above) was added for $30 \mathrm{~min}$. The plate absorbance was detected as previously described above. Calculation of the competitive ELISA 
was determined using the following formula:

inhibition $(\%)=\frac{(\mathrm{OD} \text { max }-\mathrm{BKG})-(\mathrm{OD} \text { sample-BKG })}{(\mathrm{OD} \max -\mathrm{BKG})} \times 100$

\subsection{T-cell proliferation assays}

To determine proliferative responses of T-cells, PBS (control) or METH-modified BSA were added to 96 -well flat bottom plates at a concentration of $50 \mu \mathrm{g} / \mathrm{ml}$. T-cells from immunized and sham immunized (vehicle control) rats were added at a concentration of $\left(1 \times 10^{5}\right.$ cells/well) and incubated for $48 \mathrm{~h}$ at $37^{\circ} \mathrm{C}$ in $5 \% \mathrm{CO}_{2}$, pulsed with $1.0 \mu \mathrm{Ci} /$ well of $\left[{ }^{3} \mathrm{H}\right]$ thymidine (GE Healthcare, Piscataway, $\mathrm{NJ}$ ) for $16 \mathrm{~h}$, and harvested on a 96-well harvester (Tomtec, Orange, $\mathrm{CO})$. Filter paper containing the incorporated thymidine was placed in scintillation fluid and counted on a 1450 Microbeta Scintillation Counter (Perkin Elmer Life Sciences, Waltham, MA). Data was expressed as stimulation index (SI) using the following formula:

$\mathrm{SI}=\frac{(\text { mean } \mathrm{cpm} / \mathrm{min} \text { of target }-\mathrm{BKG})}{(\text { mean } \mathrm{cpm} / \mathrm{ml} \text { of control }-\mathrm{BKG})}$

\subsection{Self-administration apparatus}

Eight standard self-administration chambers (Med-Associates, Georgia, VT, USA) were used each housed in a PVC soundattenuating cubicle fitted with an exhaust fan and a house light. Each chamber $(30.5 \mathrm{~cm} \times 24.1 \mathrm{~cm} \times 21 \mathrm{~cm} ; 1 \times w \times h)$ had side walls made of aluminum; the ceiling and front and back walls were clear polycarbonate. In the bottom center of one aluminum wall was a recessed dipper receptacle $(5.2 \mathrm{~cm} \times 5.2 \mathrm{~cm} \times 3.8 \mathrm{~cm} ; 1 \times w \times d)$. The dipper arm, when raised, allowed access to $0.1 \mathrm{ml}$ of $26 \%$ sucrose solution $(w / v)$. Retractable levers were located on either side of the dipper receptacle. To operate the lever required $147 \mathrm{nN}$ of force. Two white cue lights $(28 \mathrm{~V}, 100 \mathrm{~mA})$ were centered $7 \mathrm{~cm}$ above each lever, $14.6 \mathrm{~cm}$ above the metal rod floor and $3.5 \mathrm{~cm}$ from the closest polycarbonate wall. Each chamber contained a balanced metal arm with a spring leash attached to a swivel. Tygon ${ }^{\circledR}$ tubing AAQ04103 (VWR, West Chester, PA, USA) extended through the leash and was connected to a $5 \mathrm{ml}$ syringe mounted on an infusion pump (Med Associates, PMH-100VS) located outside of the PVC cubicle.

\subsection{Meth self-administration methods}

\subsubsection{Subjects}

Ten male Wistar rats weighing 150-175g upon arrival from Charles River Laboratories, Inc. (Wilmington, MA, USA) were housed individually in clear polycarbonate tubs lined with wood shavings. Water was continuously available in the home cage and access to chow was restricted during Preliminary Training and Self-Administration. All sessions were conducted during the light portion of a $12 \mathrm{~h} \mathrm{light/dark} \mathrm{cycle.} \mathrm{Experimental} \mathrm{protocols} \mathrm{were}$ approved by the University of Nebraska-Lincoln and University of Nebraska Medical Center Institutional Animal Care and Use Committee and followed the "Guide for the Care and Use of Laboratory Animals" (National Research Council, 1996).

\subsubsection{Drug}

D-Methamphetamine hydrochloride (meth) was purchased from Sigma (St. Louis, MO, USA), dissolved in $0.9 \%$ sterile saline $(\mathrm{w} / \mathrm{v})$, and administered intravenously (IV) at a volume of $36 \mu \mathrm{l}$ per infusion.

\subsection{Preliminary training}

Rats were fed $20 \mathrm{~g}$ of chow per day during this phase. Dipper training consisted of a 50 min automated session in which the probability of receiving $4 \mathrm{~s}$ access to sucrose in any $4 \mathrm{~s}$ interval was
0.1333 (ca. 3 deliveries per min). Two days of lever press autoshaping following dipper training. On a given session only one of the retractable levers (right or left) was inserted into the chamber for $15 \mathrm{~s}$ using a variable time $60 \mathrm{~s}$ schedule. If a lever press occurred before $15 \mathrm{~s}$, the lever was retracted and sucrose was immediately available for $4 \mathrm{~s}$. If no lever press occurred after $15 \mathrm{~s}$, the lever was retracted and $4 \mathrm{~s}$ access to sucrose was provided. Order of lever presentation (left or right on day 1) was counterbalanced as much as allowed by sample size. There were 60 presentations of the lever per session; thus, session length varied somewhat between rats depending upon when consistent lever pressing developed in the session. After the last autoshaping session, rats were allowed free access to rat chow until the end of the surgical recovery period.

\subsection{Catheter surgery}

Surgery was performed $24 \mathrm{~h}$ after the last vaccination and proceeded as described in detail elsewhere $[26,27]$. Briefly, rats were anesthetized with $1 \mathrm{ml} / \mathrm{kg}$ ketamine hydrochloride $(100 \mathrm{mg} / \mathrm{ml}, \mathrm{IP}$ ) followed by $0.6 \mathrm{ml} / \mathrm{kg}$ xylazine hydrochloride $(20 \mathrm{mg} / \mathrm{ml}$, IP) (Midwestern Veterinary Supply, Des Moines, IA, USA). One end of a silastic catheter (CamCaths ${ }^{\mathcal{C}}$ IVSA28, Ely, Cambridgeshire, UK) was implanted into the left external jugular vein. The other end of the catheter went subcutaneous around the shoulder and was attached to a metal cannula embedded in a plastic bolt that exited below the scapula permitting access to the catheter. To manage post-surgical pain, buprenorphine hydrochloride $(0.1 \mathrm{mg} / \mathrm{kg}$; Sigma) was injected SC immediately following surgery. For that evening and the following day buprenorphine $(0.5 \mathrm{mg} / \mathrm{kg})$ was available in the drinking water. The catheter was flushed twice a day with $0.2 \mathrm{ml}$ of sterile heparinized saline ( $30 \mathrm{U} / \mathrm{ml}$; Midwest Veterinary Supply). The first five post-surgical flushes also included $0.1 \mathrm{ml}$ of streptokinase (ca. $8000 \mathrm{U} / \mathrm{ml}$; Sigma) dissolved in heparinized saline. Catheter patency of the 10 rats was confirmed with a $0.05 \mathrm{ml}$ IV infusion of xylazine $(20 \mathrm{mg} / \mathrm{ml})$ at the end of the study. This concentration produces motor ataxia within $5 \mathrm{~s}$ if the catheter is patent.

\subsection{Self-administration}

Five days after surgery (7 days after the last vaccination) rats started the self-administration phase. Sessions were $60 \mathrm{~min}$ and the house light remained on throughout each session. Which lever (right or left) functioned as the active (drug) lever was counterbalanced as permitted by sample size. The initial schedule of reinforcement was a fixed ratio(FR) 1 . Thus, each active lever press produced a $1 \mathrm{~s}$ infusion of $0.05 \mathrm{mg} / \mathrm{kg}$ meth and simultaneous illumination of the cue light above the active lever. Both levers were retracted and remained retracted for 1 min following completion of the FR1. Inactive lever presses were recorded but had no programmed consequence. Rats remained on an FR1 for 5 days. This schedule was increased to an FR3 (5 days), followed by an FR5 (5 days), an FR10 (3 days), and finally a progressive ratio (1 day). Increments in the progressive ratio (PR) schedule within session used the formula $5 \times \operatorname{EXP}(0.2 \times$ infusion number $)-5[28,29]$. Similar to those studies, we replaced the first six values $(1,2,4,6,9$, and 12) with 3 , 6 , and 10 , and then continued with the progression provided by the equation. The resulting sequence of required responses per infusion was: $3,6,10,15,20,25,32,40,50,62,77,95,118,145$, 179, etc. [Note: For the blood sample section the first blood collection was approximately $24 \mathrm{~h}$ after the PR schedule. The second sample was taken 34 days later].

\subsection{Dependent measures and data analysis}

For each FR schedule, the number of methamphetamine infusions was analyzed with a 2-way mixed analysis of variance 
Table 1

EP54 containing vaccines to methamphetamine.

\begin{tabular}{ll}
\hline Vaccine 1 & METH-YSFKPMPLaR \\
Vaccine 2 & METH-YSYFPSVYSFKPMPLaR \\
Vaccine 3 & METH \\
& METH-K-YSFKPMPLaR \\
Vaccine 4 & METH \\
\hline
\end{tabular}

(ANOVA) with Group (Vaccine or Control) as the between-subjects factor and Session as the within-subjects factor. To determine when discrimination between the active and inactive lever was acquired, the ratio of active to total lever presses was calculated and then compared to a hypothetical mean of 0.5. Acquisition of the discrimination was declared when two consecutive session were significantly above 0.5 (i.e., more than half the total responding on the active lever). For the PR schedule, the last PR completed (i.e., breakpoint) for each group was compared with an unpaired $t$ test. Statistical significance for all analyses was set at $P<0.05$ with a two-tailed rejection region.

\section{Results}

Four molecular adjuvant (EP54)-containing vaccines were used in this study and are shown in Table 1 . They consisted of two monovalent vaccines (Vaccines 1 and 2 ) and two divalent vaccines (Vaccines 3 and 4). Fig. 1 shows increased serum Ab reactivity at week 6 to the METH hapten for Vaccine $2(1716 \mathrm{ng} / \mathrm{ml} \pm 211)$ and Vaccine $4(858 \mathrm{ng} / \mathrm{ml} \pm 91) P \leq 0.001$ compared to serum from rats sham immunized with vehicle only $(40 \mathrm{ng} / \mathrm{ml} \pm 15$ ). Relative to the other EP54-containing vaccines, Vaccine 2 appeared to generate the highest serum Ab titers to METH $(P \leq 0.001)$ and, therefore, was chosen for use in subsequent experiments.

The specificity of these anti-METH Abs generated by Vaccine 2 to methamphetamine was determined using a binding inhibition assay to the METH hapten in the presence of authentic methamphetamine. Fig. 2 indicates an 80\% inhibition of the METH-positive rat serum in the presence of free methamphetamine, demonstrating $\mathrm{Ab}$ specificity to the drug.

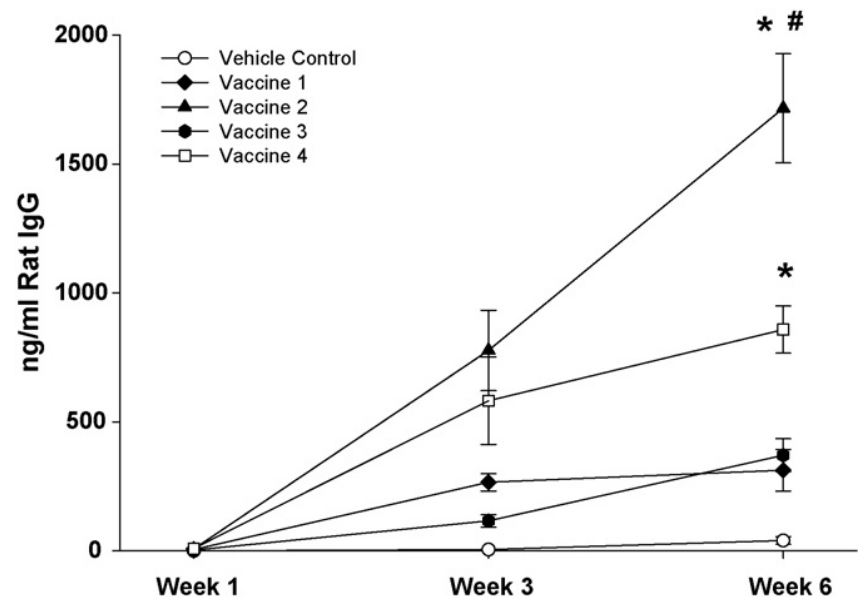

Fig. 1. Ab activity to methamphetamine in male Wistar rats immunized with: vehicle control (PBS); METH-YSFKPMPLaR (Vaccine 1); METH-YSYFPSVYSFKPMPLaR (Vaccine 2); METH-K(METH)YSFKPMPLaR (Vaccine 3); and METH-K(METH)YSYFPSVYSFKPMPLaR (Vaccine 4) at weeks 1, 3 and 6. Serum from rats was screened using METH-modified BSA as the antigen and extrapolated using rat IgG as a standard curve. Each bar represents the mean \pm S.E. of 4 rats. ${ }^{*} P \leq 0.001$, significantly different from the vehicle control. ${ }^{\#} P \leq 0.001$ significantly different form all other vaccines.

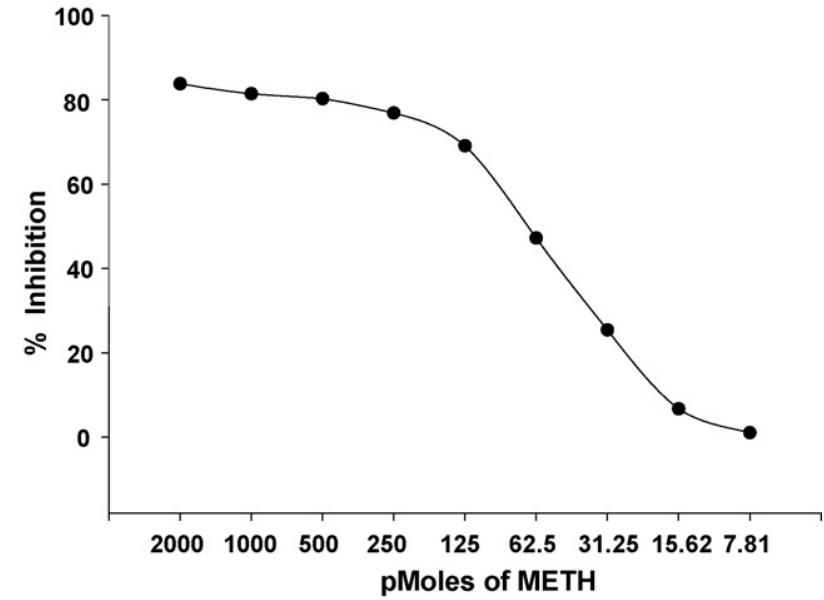

Fig. 2. An example of $\mathrm{Ab}$ specificity to meth from rats vaccinated with Vaccine 2. Sera were incubated in the presence of authentic meth as an inhibitor and then allowed to bind the METH-modified BSA antigen. Data are expressed as \% inhibition of immune sera. Data are representative of 4 rats.

Vaccines 2 and 4 incorporated the T-cell epitope YSYFPSV from tetanus toxin ( $\mathrm{TT}_{593-599}$ ) as a component for generating $\mathrm{CD}^{+} \mathrm{T}$-cell help in the production of anti-METH/meth Abs [25]. To determine the involvement of this T-cell help, T-cells from spleens of $\mathrm{METH} /$ meth-positive rats immunized with Vaccines 2 and 4 were isolated and incubated with BSA modified with METH or a vehicle control. Fig. 3 shows an increased stimulation index $(6.8 \pm 0.87)$ for Vaccine 2 and $(3.5 \pm 1.1)$ for Vaccine 4 when METH-modified BSA was used as the antigen relative to vehicle control ( $1.9 \pm 0.19)$, supporting the involvement of T-cell help in the production of Abs to meth. These data further indicate that Vaccine 2 would serve as the best candidate vaccine for use in self-administration studies.

To determine the ability of these anti-METH/meth Abs to reduce meth distribution to the brain, rats were immunized with Vaccine 2 and then monitored for changes in meth self-administration relative to sham-vaccinated controls. Fig. 4 shows the number of infusions earned per session across each FR schedule. The ANOVA on the infusions earned across the initial FR1 schedule indicated a main effect of Group, $F(1,8)=7.10, P=0.029$; the main effect of Session and the Group $\times$ Session interaction were not significant, $F$ 's $<1$. This analysis indicates that the Vaccine group took more meth than

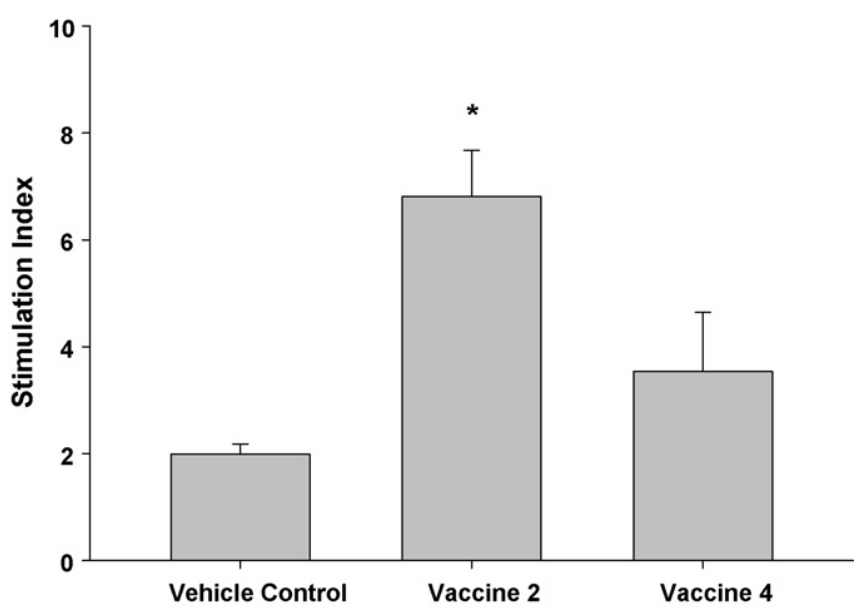

Fig. 3. T-cell proliferation assay from male Wistar rats immunized with a vehicle control, Vaccine 2, and Vaccine 3. T-cells were isolated from the spleen, incubated with a control or METH-modified BSA meth for $48 \mathrm{~h}$, and pulsed with [ $\left.{ }^{3} \mathrm{H}\right]$-thymidine overnight. Data are expressed as a stimulation index of 3 rats. ${ }^{*} P=0.002$ significantly different from the vehicle control. 


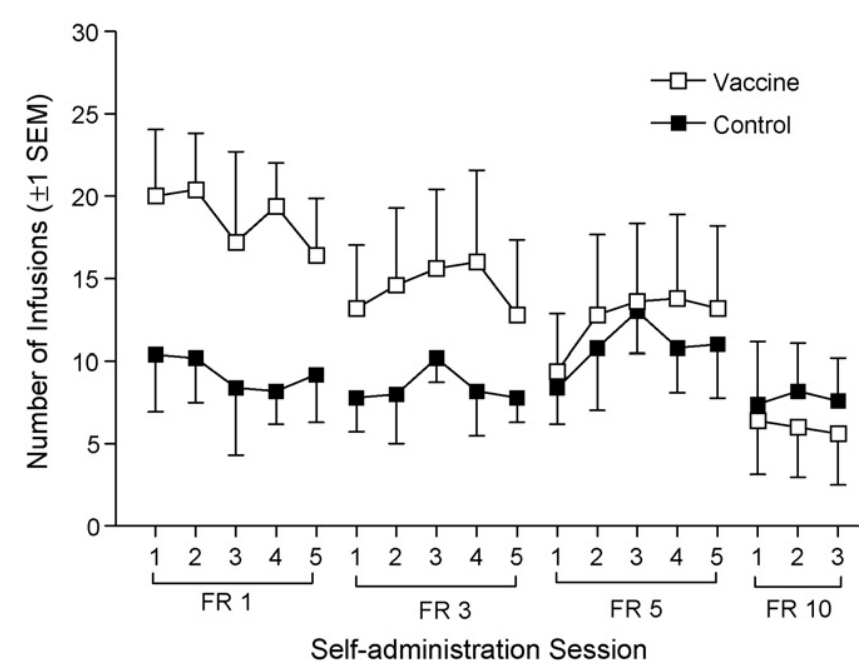

Fig. 4. Self-administration of meth following immunization with Vaccine 2. Data are expressed as the mean number of meth infusions taken per session across each fixed ratio (FR) schedule of reinforcement for rats in the Vaccine and Control groups.

the Control group during this initial phase of self-administration. As meth self-administration progressed and the reinforcement schedule increased, this difference was no longer detected: FR3 ( $F$ 's $\leq 1.7$, $p$ 's $\geq 0.226)$, FR5 ( $F s \leq 1.25, p$ 's $\geq 0.308)$, FR10 ( $F s<1)$. Both groups acquired the discrimination between the active and inactive lever (data not shown). However, onset of the discrimination was faster for the Vaccine group than the Control group. The Vaccine group had significantly more than half of their subjects responding on the active lever by Sessions 4 and 5 of the FR1, whereas the Control group did not meet the criterion until Sessions 3 and 4 of the FR3. Breakpoints on the PR schedule were highly variable and did not differ between the Vaccine $(70 \pm 34.5)$ and Control $(47 \pm 18.1)$ group, $t<1$.

Following the meth self-administration studies, the animals were checked for serum Ab titers to meth. As shown in Fig. 5 only background levels of $\mathrm{Ab}$ to the meth was observed shortly after self-administration (186 \pm 17$)$. However, following a 34-day clearance of meth, serum $A b$ titers rebounded to the previous levels $(1664 \pm 543)$ of $\mathrm{Ab}$ seen with the original immunizations of Vaccine 2 . These data indicate that the anti-meth Abs were bound by free, circulating meth during self-administration and, consequently, were masked from our binding assays.

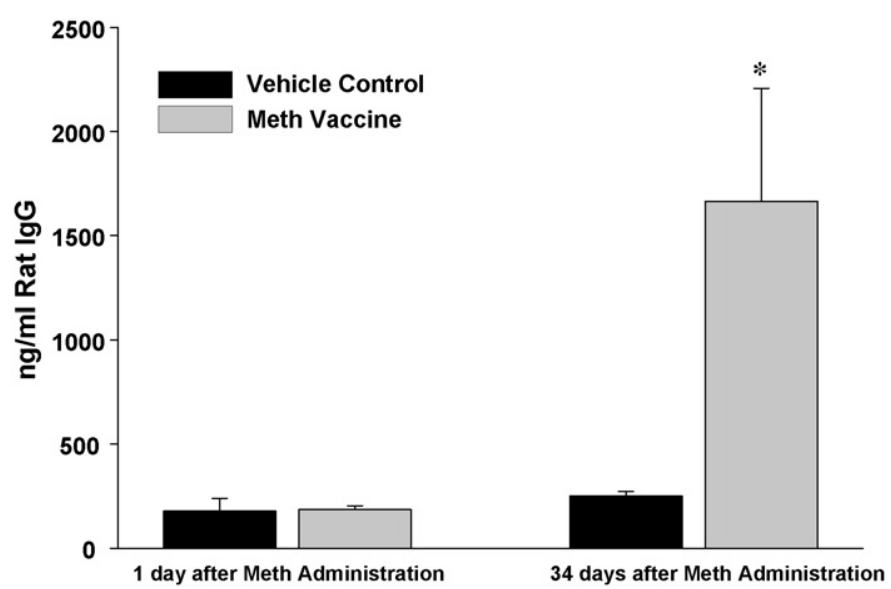

Fig. 5. Immune serum activity to METH-modified BSA 1 week after selfadministration of meth in male Wistar rats immunized with a vehicle control or Vaccine 2 . Data represent the mean \pm S.E. of $5-6$ rats. ${ }^{*} P \leq 0.001$ as compared to the vehicle control or the vaccinated rats after 1 day of meth self-administration.

\section{Discussion}

The results of this study indicate that immunization with a peptide-based, molecular adjuvant (EP54)-containing vaccine to meth (Vaccine 2) can generate meth-specific Abs in the sera of rats capable of altering meth self-administration. In contrast to the immunoconjugate vaccines to meth [16] and other addictive drugs [8-14] made by the covalent conjugation of numerous drug haptens to a carrier protein admixed with adjuvant, it is noteworthy that these anti-meth responses were generated by a vaccine that carried only one METH hapten and were produced by immunization in the absence of added adjuvant - the vaccine dissolved merely in PBS.

Development of vaccines from other laboratories has demonstrated similar Ab titers to the one described in this article. However, the majority of haptenated vaccines to nicotine, cocaine, and meth were all coupled to KLH (keyhole limpet hemocyanin) or some other large carrier protein and immunized with oil based adjuvants such as Ribi or Freunds $[14,16,30,31]$. Such drug hapten-protein conjugate vaccines to nicotine and cocaine have been taken into phases I and II trails with some success [12,32]. This present study and our previous nicotine vaccine study [15] are the first to use a novel peptide-based vaccine in the absence of large carrier proteins and the use of added adjuvants. The principal experimental approach for attenuating the effects of meth overdose/abuse is the use of anti-meth monoclonal Abs (MAbs) that are first generated in mice $[33,34]$. These MAbs are then infused into rats and then tested using self-administration studies $[35,36]$. The EP54-containing vaccines described in this study offer clear potential advantages over the use MAbs and protein-conjugate vaccines in that active immunization as often as is need is possible to invoke a sustained, protective immune response to attenuate the psychoactive effects of meth with little/no inflammatory side-effects from added adjuvants.

The immunologic results presented in this study are consistent with those observed with an EP54-containing vaccine to nicotine [15] and with a mechanism we proposed earlier to describe the molecular adjuvant properties of EP54 (YSFKPMPLaR) and its ability to induce $\mathrm{Ag}$-specific $\mathrm{Ab}$ and cell-mediated immune responses [20-24]. Briefly, EP54 selectively interacts with C5aRs on antigen presenting cells (especially DCs) and induces the release of Th1 cytokines. The C5aR/ligand complex then internalizes, which carries the covalently attached Ag/epitope into intracellular Ag processing pathways. Here, the $\mathrm{Ag} /$ epitope is processed and associates with HLA/MHC determinants for expression on the DC surface. Thus, EP54 delivers both the Ag and stimulatory signals to C5aRbearing DCs.

Vaccine 2 was designed to exploit the assistance of a promiscuous T-cell epitope (YSYFPSV) derived from tetanus toxin ( TT $\left._{593-599}\right)$. YSYFPSV is processed by DCs, presented in the context of MHC/HLA class II, and invokes $\mathrm{CD} 4^{+} \mathrm{T}$-cell help to $\mathrm{B}$ cells for the production of Abs [25]. Thus, we reasoned that METH-YSYFPSV likewise would be processed and presented by DCs, particularly when targeted to and activated by EP54. Our expectation was that the presented YSYFPSV moiety would induce the necessary $\mathrm{CD}^{+}$help for the appropriate B cell(s) to recognize the attached METH hapten, which together would drive the hapten-specific Ab response. This involvement of the $\mathrm{TT}_{593-599}$ epitope appears substantiated by the anti-METH/meth immune outcomes generated by Vaccines 2 and 4 and the relative lack of response with Vaccines 1 and 3 , which lacked this epitope. This epitope involvement in the antimeth immune outcome is further substantiated by the increased stimulation index observed from T-cells obtained from the spleens of rats immunized with Vaccine 2.

The use of $\mathrm{TT}_{593-599}$ in these EP54-containing vaccines is attractive because it is well-characterized immunologically, is small and easy to synthesize, and has been used in other larger, peptidebased vaccines to invoke $\mathrm{CD} 4^{+} \mathrm{T}$-cell help for $\mathrm{B}$ cells to generate 
Ag-specific Abs [25]. Also, it is possible that this $\mathrm{CD} 4^{+}$response in humans may be readily invoked with such TT/molecular adjuvantcontaining vaccines to meth since most people already have been immunized to tetanus.

Given the ability of Vaccine 2 to induce meth-specific Abs in serum, the efficacy of this immune outcome to reduce the psychoactive effects of meth was evaluated in meth self-administration in rats. There was a significant but transient effect of Vaccine 2 on meth self-administration. Surprisingly, vaccinated rats displayed an increase rather than a decrease in drug intake relative to controls only in the initial FR1 phase of self-administration. This pattern of results is consistent with the view that meth-specific Abs are sequestering meth in peripheral circulation, thus decreasing, at least early on, the ability of some of the meth from entering the central nervous system; i.e., meth-specific Abs are essentially functioning as a pharmacokinetic antagonist [13]. Vaccinated rats presumably compensated for this pharmacokinetic antagonism by increasing drug intake. Indeed, such compensation is seen in selfadministration experiments when pharmacological antagonists are used [28,37,38].

Following the self-administration studies, animals were tested for the presence of meth-specific Abs. These assays showed barely discernable levels of Abs, which were lower than unimmunized control animals. When these animals were allowed to recovery from meth self-administration and the sera were re-tested, antimeth $\mathrm{Ab}$ levels returned to previous levels. This suggests that the Abs bound free meth with high affinity/avidity in vivo, minimizing meth access to the brain and the need for animals to compensate by increasing self-administration. Thus, vaccinated animals behaved essentially like controls in the later phases of self-administration. It appeared that animals would take in more meth to compensate for the effects of the vaccine; however, later when all the Abs were saturated with meth, they were equal to the controls.

These data suggest that this vaccine could be useful in absorbing some of the meth in peripheral circulation early in meth exposure. However, our findings suggest that compensation may occur resulting in overall increased meth administration. This finding implies that such a vaccination approach would be most effectively used in association with standard behavior modification and the use of other medications as a complementary approach to stop meth use and addiction. Some authors have suggested that vaccination could be used as a prevention strategy for at-risk individuals $[13,38]$, whereas others have expressed some skepticism and urged extreme caution if such an approach is routinely adopted $[26,39,40]$. At least with vaccination as a preventative against meth abuse, our findings that vaccinated rats increase early meth intake suggests the latter perspective may be more appropriate. It will be of interest in future research to determine if similar compensation occurs in an animal model that simulates a relapse opportunity in a meth addict that has been abstinent for some time (i.e., as an intervention approach).

\section{Acknowledgements}

Special thanks to the Protein Structure Core Facility at UNMC for mass spectrometry analysis of the vaccines used in this study. Also, the members of the Experimental Immunology Laboratory including: Karen C. Easterling, Carlos D. Hunter, Amy L DeVeney, and Jennifer $\mathrm{C}$. Thiele.

\section{References}

[1] Substance abuse-A National Challenge: Prevention, Treatment, and Research at HHS. HSS Fact Sheet February 27, 2002.

[2] Cho AK. Ice: a new dosage form of an old drug. Science 1990;249:631-4.

[3] Sekine H, Nakahara Y. Abuse of smoking methamphetamine mixed with tobacco.I. Inhalation efficiency and pyrolysis products of methamphetamine. J Forensic Sci 1987;32:1271-80.
[4] Hutin YJ, Sabin KM, Hutwagner LC. Multiple modes of hepatitis A virus transmission among methamphetamine users. Am J Epidemiol 2000;152:18692.

[5] Ling W, Rawson R, Shoptaw S. Management of methamphetamine abuse and dependence. Curr Psychiatry Rep 2006;8:345-54.

[6] Murray JB. Psychophysiological aspects of amphetamine-methamphetamine abuse. J Psychol 1998;132:227-37.

[7] Seiden LS, Sabol KE, Ricaurte GA. Amphetamine: effects on catecholamine systems and behavior. Annu Rev Pharmacol Toxicol 1993;33:639-77.

[8] Vocci FJ, Appel NM. Approaches to the development of medications for the treatment of methamphetamine dependence. Addiction 2007;102(Suppl. 1):96-106.

[9] Fox BS, Kantak KM, Edwards MA. Efficacy of a therapeutic cocaine vaccine in rodent models. Nat Med 1996;2:1129-32.

[10] Kantak KM. Vaccines against drugs of abuse: a viable treatment option? Drugs 2003;63:341-52.

[11] Killian A, Bonese K, Rothberg RM, Wainer BH, Schuster CR. Effects of passive immunization against morphine on heroin self-administration. Pharmacol Biochem Behav 1978;9:347-52.

[12] Hieda Y, Keyler DE, Vandevoort JT. Active immunization alters the plasma nicotine concentration in rats. J Pharmacol Exp Ther 1997;283:1076-81.

[13] Kosten T, Owens SM. Immunotherapy for the treatment of drug abuse. Pharmacol Ther 2005;108:76-85.

[14] Pentel PR, Malin DH, Ennifar S. A nicotine conjugate vaccine reduces nicotine distribution to brain and attenuates its behavioral and cardiovascular effects in rats. Pharmacol Biochem Behav 2000;65:191-8.

[15] Sanderson SD, Cheruku SR, Padmanilayam MP. Immunization to nicotine with a peptide-based vaccine composed of a conformationally biased agonist of C5a as a molecular adjuvant. Int Immunopharmacol 2003;3:137-46

[16] Byrnes-Blake KA, Carroll FI, Abraham P, Owens SM. Generation of anti$(+)$ methamphetamine antibodies is not impeded by $(+)$ methamphetamine administration during active immunization of rats. Int Immunopharmacol 2001;1:329-38.

[17] Finch AM, Vogen SM, Sherman SA, Kirnarsky L, Taylor SM, Sanderson SD. Biologically active conformer of the effector region of human C5a and modulatory effects of $\mathrm{N}$-terminal receptor binding determinants on activity. J Med Chem 1997;40:877-84

[18] Kawatsu R, Sanderson SD, Blanco I. Conformationally biased analogs of human C5a mediate changes in vascular permeability. J Pharmacol Exp Ther 1996;278:432-40.

[19] Short AJ, Paczkowski NJ, Vogen SM, Sanderson SD, Taylor SM. Responseselective C5a agonists: differential effects on neutropenia and hypotension in the rat. Br J Pharmacol 1999;128:511-4.

[20] Taylor SM, Sherman SA, Kirnarsky L, Sanderson SD. Development of responseselective agonists of human C5a anaphylatoxin: conformational, biological, and therapeutic considerations. Curr Med Chem 2001;8:675-84.

[21] Buchner RR, Vogen SM, Fischer W, Thoman ML, Sanderson SD, Morgan EL. Anti-human kappa opioid receptor antibodies: characterization of site-directed neutralizing antibodies specific for a peptide kappa R(33-52) derived from the predicted amino terminal region of the human kappa receptor. J Immunol 1997; 158:1670-80.

[22] Tempero RM, Hollingsworth MA, Burdick MD. Molecular adjuvant effects of a conformationally biased agonist of human C5a anaphylatoxin. J Immunol 1997; 158:1377-82.

[23] Ulrich JT, Cieplak W, Paczkowski NJ, Taylor SM, Sanderson SD. Induction of an antigen-specific CTL response by a conformationally biased agonist of human C5a anaphylatoxin as a molecular adjuvant. J Immunol 2000;164:5492-8.

[24] Hegde GV, Meyers-Clark E, Joshi SS, Sanderson SD. A conformationally-biased, response-selective agonist of $\mathrm{C} 5 \mathrm{a}$ acts as a molecular adjuvant by modulating antigen processing and presentation activities of human dendritic cells. Int Immunopharmacol 2008;8:819-27.

[25] Krikorian D, Panou-Pomonis E, Voitharou C, Sakarellos C, Sakarellos-Daitsiotis M. A peptide carrier with a built-in vaccine adjuvant: construction of immunogenic conjugates. Bioconjug Chem 2005;16:812-9.

[26] Reichel CM, Linkugel JD, Bevins RA. Bupropion differentially impacts acquisition of methamphetamine self-administration and sucrose-maintained behavior. Pharmacol Biochem Behav 2008;89:463-72.

[27] Wilkinson JL, Bevins RA. Intravenous nicotine conditions a place preference in rats using an unbiased design. Pharmacol Biochem Behav 2008;88:25664.

[28] Barrett AC, Miller JR, Dohrmann JM, Caine SB. Effects of dopamine indirect agonists and selective D1-like and D2-like agonists and antagonists on cocaine self-administration and food maintained responding in rats. Neuropharmacology 2004:47(Suppl. 1):256-73.

[29] Donny EC, Caggiula AR, Mielke MM. Nicotine self-administration in rats on a progressive ratio schedule of reinforcement. Psychopharmacology (Berl) 1999; 147:135-42.

[30] Hieda Y, Keyler DE, Ennifar S, Fattom A, Pentel PR. Vaccination against nicotine during continued nicotine administration in rats: immunogenicity of the vaccine and effects on nicotine distribution to brain. Int J Immunopharmacol 2000;22:809-19.

[31] Kantak KM, Collins SL, Lipman EG, Bond J, Giovanoni K, Fox BS. Evaluation of anti-cocaine antibodies and a cocaine vaccine in a rat self-administration model. Psychopharmacology (Berl) 2000;148:251-62.

[32] Kosten TR, Rosen M, Bond J. Human therapeutic cocaine vaccine: safety and immunogenicity. Vaccine 2002;20:1196-204. 
[33] Danger Y, Gadjou C, Devys A, Galons H, Blanchard D, Follea G. Development of murine monoclonal antibodies to methamphetamine and methamphetamine analogues. J Immunol Methods 2006;309:1-10.

[34] Laurenzana EM, Byrnes-Blake KA, Milesi-Halle A, Gentry WB, Williams DK, Owens SM. Use of anti-(+)-methamphetamine monoclonal antibody to significantly alter (+)-methamphetamine and (+)-amphetamine disposition in rats. Drug Metab Dispos 2003;31:1320-6.

[35] Byrnes-Blake KA, Laurenzana EM, Landes RD, Gentry WB, Owens SM. Monoclonal IgG affinity and treatment time alters antagonism of (+)methamphetamine effects in rats. Eur J Pharmacol 2005;521:86-94.

[36] McMillan DE, Hardwick WC, Li M. Effects of murine-derived antimethamphetamine monoclonal antibodies on (+)-methamphetamine self-administration in the rat. J Pharmacol Exp Ther 2004;309:1248 55.

[37] Depoortere RY, Li DH, Lane JD, Emmett-Oglesby MW. Parameters of selfadministration of cocaine in rats under a progressive-ratio schedule. Pharmacol Biochem Behav 1993;45:539-48.

[38] Weissenborn R, Deroche V, Koob GF, Weiss F. Effects of dopamine agonists and antagonists on cocaine-induced operant responding for a cocaine-associated stimulus. Psychopharmacology (Berl) 1996;126:311-22.

[39] Bevins RA, Wilkinson JL, Sanderson SD. Vaccines to combat smoking. Expert Opin Biol Ther 2008;8:379-83.

[40] Vocci FJ, Chiang CN. Vaccines against nicotine: how effective are they likely to be in preventing smoking? CNS Drugs 2001;15:505-14. 